\title{
THE OPTIMAL CONTROL PROBLEM FOR OUTPUT MATERIAL FLOW ON CONVEYOR BELT WITH INPUT ACCUMULATING BUNKER
}

\author{
O.M. Pihnastyi ${ }^{1}$, V.D. Khodusov ${ }^{2}$ \\ ${ }^{1}$ National Technical University "Kharkiv Polytechnic Institute", Kharkov, Ukraine \\ ${ }^{2}$ V.N. Karazin Kharkiv National University, Kharkov, Ukraine \\ E-mails: pom7@bk.ru,vkhodusov@ukr.net
}

\begin{abstract}
The article is devoted to the synthesis of optimal control of conveyor belt with the accumulating input bunker. Much attention is given to the model of the conveyor belt with a constant speed of the belt. Simulation of the conveyor belt is carried out in the onemoment approximation using partial differential equations. The conveyor belt is represented as a distributed system. The used PDE-model of the conveyor belt allows to determine the state of the flow parameters for a given technological position as a function of time. We consider the optimal control problem for flow parameters of the conveyor belt. The problem consists in ensuring the minimum deviation of the output material flow from a given target amount. The control is carried out by the material flow amount, which comes from the accumulating bunker into the conveyor belt input. In the synthesis of optimal control, we take into account the limitations on the size of the accumulating bunker, as well as on both max and min amounts of control. We construct optimal control of the material flow amount coming from the accumulating bunker. Also, we determine the conditions to switch control modes, and estimate time period between the moments of the switching.

Keywords: conveyor; production line; subject of labour; PDE-model of production; parameters of the state of the production line; technological position; transition period; production control systems; optimal control; Pontryagin function; Lagrange function; differential constraints; accumulating bunker; distributed system.
\end{abstract}

\section{Introduction}

There are two fundamentally different methods to control the output flow of the conveyor belt. The first method is to regulate the conveyor belt speed [1-5]. The second method is to use the accumulating bunker at the conveyor input [6-8]. Output flow control is performed with a certain delay by changing the amount of material at the conveyor input. As a rule, the second method is carried out for a constant speed of the belt. The method to regulate the conveyor belt speed is used to reduce consumption of the energy $[9,10]$. This is due to the fact that in most cases the conveyor systems function in modes significantly different from the normative ones. Time-varying flow amount at the conveyor input has significant influence on uneven load of the belt along the transport route in the case of unregulated drive conveyor [11]. Regulation of the belt speed gives the transport system an ability to function in the normative mode such that the electricity consumption for transporting the rock of a unit mass is minimum. According to DIN 22101 (Germany) [10], the energy consumption for the belt conveyor is expected to be reduced. At the same time, the potential risks of failure of the conveyor belt elements are significantly increased. Indeed, the frequent transition from one mode of the belt speed to another [12] leads to significant financial costs. In transition modes, a change in the speed of the conveyor belt leads to belt tension, which is the main reason for the belt breaking 
in the splicing region [12]. In order to design a transport system, it is necessary to take into account other risks that arise as a result of the functioning of the conveyor belt in a transition mode: slip of the belt around the drive pulley, leakage of material away from the belt, engine overheating. Along with the potential risks of destroying the transport system, an important problem is the dynamic analysis of the transport systems both with a mode to regulate the belt speed and without such a mode [1]. The dynamic analysis is difficult, since a conveyor with a rock moving along the transport route is a distributed system with a number of limitations. The most important limitations are the maximum specific linear load of the conveyor belt and the maximum amount of the transported mass [13]. The conveyor system is statistically uncertain. Statistical uncertainty consists in the uncertainty of the value of material flow to the input of the conveyor (uncertainty of the boundary conditions) which requires using the probabilistic methods for calculating the conveyor line [14]. We focus on the construction of an optimal control of the material flow of the main conveyor belt equipped with an input accumulating bunker. In the transport system that moves a rock to the port terminal, the material flow at the conveyor output should vary depending on the loading capacities of vessels, as well as the schedule of dry cargo loading. This is achieved due to the fact that the material flow enters the accumulating input bunker. Control of the flow amount that enters the conveyor belt input allows to form the material flow required at the transport system output. In order to construct optimal control of the material flow on the main conveyor belt, we assume that the conveyor belt speed is constant. There is no ability to regulate the conveyor belt speed. The output material flow can be provided by the presence of an accumulating bunker and a system to control the material flow that enters the transport system input. A spiral belt conveyor can be used as an accumulating input equipment. The use of such accumulating types of equipment is justified for the organization of technological routes that require simultaneous accumulation and movement of products in the production process with vertical and horizontal directions. The material flow from the accumulating device to the input of the main conveyor is carried out by adjusting the belt speed in the spiral conveyor.

\section{Problem Statement}

We construct a distributed model of the main conveyor belt and determine optimal control of the material flow on the main conveyor belt equipped with an accumulating bunker. To this end, we consider the following individual problems.

1. Construct a model of a distributed transport system with an input accumulating bunker.

2. Construct a program of optimal control of flow at the conveyor belt input with an input accumulating bunker.

3. Determine the optimal value of the capacity of an input accumulating bunker and the dependence of the optimal capacity value on the length of the transport system.

4. Calculate the duration of the transition period during which the conveyor belt is filled with rock along the entire transportation route. Determine the delay time, which is fixed by the time interval between the time of arrival of the element on the conveyor belt input and the time of its exit from the conveyor belt output. 


\section{Model of Conveyor}

Conveyor system is a type of production system with flow method of production organization. A distinctive feature of conveyor systems is that the elements move along the transport route with the same speed equal to the conveyor belt speed. The model of the production line in one-moment approximation can be represented as follows [15, p.67], [16, p.936]:

$$
\begin{gathered}
\frac{\partial[\chi]_{0}(\mathrm{t}, \mathrm{S})}{\partial t}+\frac{\partial[\chi]_{1}(\mathrm{t}, \mathrm{S})}{\partial S}=0 \\
{[\chi]_{1}(\mathrm{t}, \mathrm{S})=[\chi]_{1 \psi}(\mathrm{t}, \mathrm{S})}
\end{gathered}
$$

with the initial condition

$$
[\chi]_{0}(0, S)=\Psi(\mathrm{S})
$$

and the boundary conditions at the input of the production line

$$
[\chi]_{1}(\mathrm{t}, 0)=\lambda(\mathrm{t})
$$

where $S_{d}$ is a coordinate of the technological position for the final operation; $[\chi]_{0}(\mathrm{t}, \mathrm{S}),[\chi]_{1}(\mathrm{t}, \mathrm{S})$ are a distribution density and a tempo of processing of labor subjects at the time $t$ at the technological position, characterized by the coordinate $S \in\left(0 ; S_{d}\right)$; $\Psi(\mathrm{S})$ is an initial distribution of labor subjects along the technological route; $[\chi]_{1 \psi}(\mathrm{t}, \mathrm{S})$ is a given normative tempo of processing labor subjects at technological positions as defined in the technological production documentation; $\lambda(\mathrm{t})$ is a tempo of entry of labor subjects into the input of the production line. Conveyor is a type of production line. The main feature of a conveyor simulation for an industrial enterprise is that labor subjects move at the same speed along the conveyor belt. Therefore, we can write system of equations (1) - (4) in the following form [5]:

$$
\begin{gathered}
\frac{\partial[\chi]_{0}(\mathrm{t}, \mathrm{S})}{\partial t}+\frac{\partial[\chi]_{1}(\mathrm{t}, \mathrm{S})}{\partial S}=\delta(\mathrm{S}) \lambda(\mathrm{t}) \\
{[\chi]_{1}(\mathrm{t}, \mathrm{S})=a(t)[\chi]_{0}(\mathrm{t}, \mathrm{S}),} \\
{[\chi]_{0}(0, \mathrm{~S})=\mathrm{H}(\mathrm{S}) \Psi(\mathrm{S}), \quad \int_{-\infty}^{\infty} \delta(S) d S=1, \quad \mathrm{H}(\mathrm{S})= \begin{cases}0, & \text { if } S<0 \\
1, & \text { if } S \geqslant 0 .\end{cases} }
\end{gathered}
$$

The flow parameters $[\chi]_{0}(t, S)$ and $[\chi]_{1}(t, S)$ are related to each other by the factor $a=a(t) \frac{\text { meter }}{\text { hour }}$, which determines the conveyor belt speed. The right-hand side of equation (5), i.e. $\delta(\mathrm{S}) \lambda(\mathrm{t})$, takes into account the source of material entered for the first technological operation $(S=0)$, and $\delta(\mathrm{S})$ is the delta function. The intensity of the rock receipt to the conveyor belt is represented by the function $\lambda(\mathrm{t}) \frac{\text { ton }}{\text { hour }}$ characterizing the line power. At the initial time $t=0$ (hour) the material is distributed along the conveyor belt with a linear density $[\chi]_{0}(0, S) \frac{\text { ton }}{\text { meter }}$. The function $\delta(S)$ determines the point of the material receipt to the conveyor belt: $S=0$. System of equations (5), (6) is closed with respect to the flow parameters $[\chi]_{0}(t, S)$ and $[\chi]_{1}(t, S)$. Condition (6) reflects the functioning of the conveyor belt having condition (2) in system of equations (1) - (4). Note that condition (2) for the simulation of production lines is approximated in the one-moment description [17]. Precision of the approximation is determined by the number $N_{m}$ of labor subjects that are 


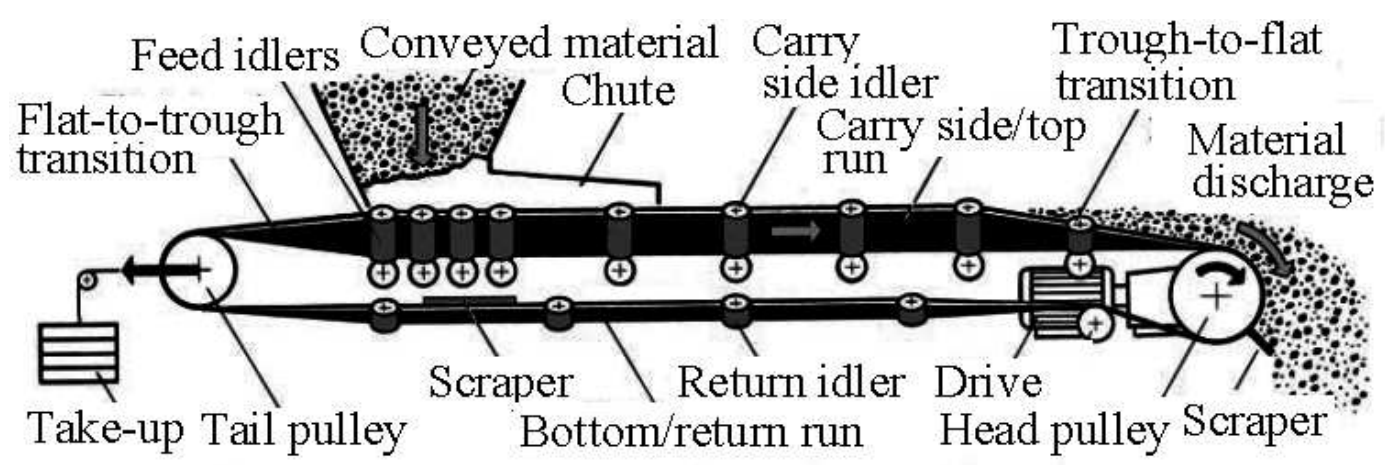

Fig. 1. Schematic diagram of the conveyor belt [12]

in inter-operational reserves before each of $m$ technological operations [18]. For $N_{m} \rightarrow \infty$ in an approximate equality, equation (2) becomes an exact equality. Therefore, condition (6) allows to construct an exact solution to system of equations (5) - (7) with respect to the flow parameters $[\chi]_{0}(\mathrm{t}, \mathrm{S})$ and $[\chi]_{1}(\mathrm{t}, \mathrm{S})$. Let us divide the technological route with a length $S_{d}$ into $M$ sections with lengths $\Delta S_{m}=S_{m}-S_{m-1}, S_{0}=0$, and integrate equation (5) within a section of length $\Delta S_{m}$ :

$\int_{S_{m-1}}^{S_{m}} \frac{\partial[\chi]_{0}(\mathrm{t}, \mathrm{S})}{\partial t} d S+\int_{S_{m-1}}^{S_{m}} \frac{\partial[\chi]_{1}(\mathrm{t}, \mathrm{S})}{\partial S} d S=\int_{S_{m-1}}^{S_{m}} \delta(\mathrm{S}) \lambda(\mathrm{t}) d S= \begin{cases}\lambda(\mathrm{t}), & \text { if } S_{m-1}=0 \\ 0, & \text { if } S_{m-1} \neq 0 .\end{cases}$

Since

$$
\begin{gathered}
\int_{S_{m-1}}^{S_{m}} \frac{\partial[\chi]_{0}(\mathrm{t}, \mathrm{S})}{\partial t} d S=\frac{\partial}{\partial t} \int_{S_{m-1}}^{S_{m}}[\chi]_{0}(\mathrm{t}, \mathrm{S}) d S=\frac{d N_{m}}{d t}, \int_{S_{m-1}}^{S_{m}}[\chi]_{0}(\mathrm{t}, \mathrm{S}) d S=N_{m}, \\
\int_{S_{m-1}}^{S_{m}} \frac{\partial[\chi]_{1}(\mathrm{t}, \mathrm{S})}{\partial S} d S=[\chi]_{1}\left(\mathrm{t}, \mathrm{S}_{\mathrm{m}}\right)-[\chi]_{1}\left(\mathrm{t}, \mathrm{S}_{\mathrm{m}-1}\right),
\end{gathered}
$$

equation (8) can be represented in the following form:

$$
\frac{d N_{1}}{d t}=\lambda(\mathrm{t})-[\chi]_{1}\left(\mathrm{t}, \mathrm{S}_{1}\right), \quad \frac{d N_{m}}{d t}=[\chi]_{1}\left(\mathrm{t}, \mathrm{S}_{\mathrm{m}-1}\right)-[\chi]_{1}\left(\mathrm{t}, \mathrm{S}_{\mathrm{m}}\right), \quad[\chi]_{1}(\mathrm{t}, 0)=0 .
$$

The condition $[\chi]_{1}(\mathrm{t}, 0)=0$ means that, if there is no source of material receipt, i.e. $\lambda(\mathrm{t})=0$, then the material flow at the conveyor belt input is zero. If the section $\Delta S_{m}$ corresponds to the $m$-th technological operation of the production line, then equations (10), (11) determine the state of the interoperational stocks before the $m$-th technological operation. System of equations (11) clearly demonstrates how the intensity $\lambda(\mathrm{t})$ of the source of supply of materials and its location affect the state of interoperational stocks along the technological route of the production line. A schematic diagram of the main conveyor belt with an accumulating bunker at the input is shown in Fig. 1 [12]. The flow of the material (for example, a rock) should enter the conveyor belt from the accumulating bunker with the intensity necessary to provide the required specified flow at the output. We supply system of equations (5) - (7) with the following equation simulating work process of the accumulating bunker:

$$
\frac{d N_{0}(t)}{d t}=\lambda_{\mathrm{b}}(\mathrm{t})-\lambda(\mathrm{t}), \quad N_{0}(0)=N_{0_{s t}}, \quad 0 \leqslant N_{0}(t) \leqslant N_{b}, \quad 0 \leqslant \lambda \leqslant \lambda_{\max },
$$


where $N_{0}(t)$ is the current number of materials in the accumulating bunker with capacity $N_{b}$. The flow of materials at the accumulating bunker input $\lambda_{\mathrm{b}}(\mathrm{t})$ is known. Also, assume that the required flow $\sigma(t)$ is set at the output of the transport system. The required flow is determined by the shipping schedule of the rock to the consumer. Let us represent system of equations $(5)-(7),(11)$ in the dimensionless form. In this case, the states of the conveyor parameters are described by dimensionless variables [5]:

$$
\begin{gathered}
\tau=\frac{t}{T_{d}}, \quad \xi=\frac{S}{S_{d}}, \quad \gamma(\tau)=\frac{\lambda(\mathrm{t})}{\Theta} \frac{T_{d}}{S_{d}}, \quad \gamma_{\mathrm{b}}(\tau)=\frac{\lambda_{\mathrm{b}}(\mathrm{t})}{\Theta} \frac{T_{d}}{S_{d}} \\
\theta_{0}(\tau, \xi)=\frac{[\chi]_{0}(\mathrm{t}, \mathrm{S})}{\Theta}, \quad \psi(\xi)=\frac{\Psi(\mathrm{S})}{\Theta}, \quad n_{0}(\tau)=\frac{N_{0}(t)}{S_{d} \Theta}, \quad \vartheta(\tau)=\sigma(t) \frac{T_{d}}{S_{d} \Theta} \\
g(\tau)=\frac{a(t) T_{d}}{S_{d}}, \Theta=\max \left\{\Psi(\mathrm{S}), \frac{\lambda(\mathrm{t})}{a(t)}\right\}, a(t) \neq 0, \delta(\xi)=S_{d} \delta(\mathrm{S}), H(\xi)=H(S) .
\end{gathered}
$$

If the control program allows the conveyor to stop $(a(t)=0)$, then $\Theta=$ $\max \left\{\Psi(S),[\chi]_{0 \max }\right\}$, where $[\chi]_{0 \max }$ is a maximum permissible running load per belt. Note that at the dimensionless value $n_{0}(\tau)=1,0, \quad \Theta=[\chi]_{0 \max }$, the accumulating bunker contains amount of material that allow to fill the conveyor belt with the maximum permissible load $N_{0}(t)=S_{d} \Theta$ along the entire length of the belt. Taking into account the introduced notation, we write balance equation $(13)$ - (14) in the dimensionless form [5]:

$$
\begin{gathered}
\frac{\partial \theta_{0}(\tau, \xi)}{\partial \tau}+g(\tau) \frac{\partial \theta_{0}(\tau, \xi)}{\partial \xi}=\delta(\xi) \gamma(\tau), \\
\theta_{0}\left(\tau_{0}, \xi\right)=\mathrm{H}(\xi) \psi(\xi), \\
\frac{d n_{0}(t)}{d t}=\gamma_{\mathrm{b}}(\tau)-\gamma(\tau), \quad n_{0}(0)=n_{0_{s t}}, \quad 0 \leqslant n_{0}(t) \leqslant n_{b}, \quad 0 \leqslant \gamma(\tau) \leqslant \gamma_{\max } .
\end{gathered}
$$

The solution to system of equations (16) - (17) is as follows [5]:

$$
\begin{gathered}
\theta_{0}(\tau, \xi)=(\mathrm{H}(\xi)-H(\xi-G(\tau))) \frac{\gamma\left(G^{-1}(G(\tau)-\xi)\right)}{g\left(G^{-1}(G(\tau)-\xi)\right)}+H(\xi-G(\tau)) \psi(\xi-G(\tau)) \\
\int g(\tau) d \tau=G(\tau), \quad G^{-1}(G(\tau))=\tau .
\end{gathered}
$$

For the conveyor belt speed $g(\tau)=g_{0}$, we have $G(\tau)=g_{0} \tau$, therefore

$$
\theta_{0}(\tau, \xi)=\left(\mathrm{H}(\xi)-H\left(-\xi+g_{0} \tau\right)\right) \frac{\gamma\left(\tau-\xi / g_{0}\right)}{g_{0}}+H\left(\xi-g_{0} \tau\right) \psi\left(\xi-g_{0} \tau\right)
$$

Expression (19) determines the state of the density of the material $\theta_{0}(\tau, \xi)$ distribution along the transport route $\xi$ at an arbitrary time $\tau$. Let us consider the functioning of the transport system for time $\tau-\frac{1,0}{g_{0}} \geqslant 0$. Speed switching modes of the conveyor belt are not taken into account. Using equation (19), we reduce system of equations (16) - (18) to the form:

$$
\begin{aligned}
& \theta_{0}(\tau, \xi)=\frac{\gamma\left(\tau-\xi / g_{0}\right)}{g_{0}}, \quad \frac{d n_{0}(t)}{d t}=\gamma_{\mathrm{b}}(\tau)-\gamma(\tau), \\
& n_{0}(0)=n_{0 s t}, \quad 0 \leqslant n_{0}(t) \leqslant n_{b}, \quad 0 \leqslant \gamma(\tau) \leqslant \gamma_{\max } .
\end{aligned}
$$

In order to determine the linear density $\theta_{0}(\tau, \xi)$ at a time $\tau$ at an arbitrary point $\xi$ of the route, it is necessary to know the value of the input material flow $\lambda(\mathrm{t})$ on the conveyor 
belt at the time $\tau_{\xi}=\tau-\xi / g_{0}$ that is fixed by the measuring-weighing equipment of the conveyor belt. The relationship between the values of the linear density $\theta_{0}(\tau, \xi)$ at arbitrary points of the transport route $\xi_{1}$ and $\xi_{2}$ at a constant speed of the conveyor belt was studied in detail in [19]. The flow of material at the input and output of the conveyor belt can be determined from (20)

$$
\theta_{1}(\tau, 1)=g_{0} \theta_{0}(\tau, 1)=\gamma\left(\tau-1 / g_{0}\right), \quad \theta_{1}(\tau, 0)=g_{0} \theta_{0}(\tau, 0)=\gamma(\tau) .
$$

\section{Optimal Control Problem for Material Flow Coming from Accumulating Bunker}

We consider the conveyor as an object of the control whose motion is described by system of differential equations (16), (20):

$$
\begin{gathered}
\frac{\partial \theta_{0}(\tau, \xi)}{\partial \tau}+g(\tau) \frac{\partial \theta_{0}(\tau, \xi)}{\partial \xi}=\delta(\xi) u(\tau), \quad \tau \in\left[0, \tau_{k}\right] \\
\frac{d n_{0}(t)}{d t}=\gamma_{\mathrm{b}}(\tau)-u(\tau), \quad \gamma(\tau)=u(\tau) .
\end{gathered}
$$

Control $u(\tau)$ is carried out by regulating the intensity $\gamma(\tau)$ of the supply of materials from the accumulating bunker (Fig. 1). We select the control quality criterion from the condition of a minimum of the integral at the time interval $\tau \in\left[0, \tau_{k}\right]$

$$
\begin{gathered}
\int_{0}^{\tau_{k}}\left|\theta_{1}(\tau, 1)-\vartheta(\tau)\right| d \tau=A+\int_{\tau_{0}}^{\tau_{k}}\left|u\left(\tau-\tau_{0}\right)-\vartheta(\tau)\right| d \tau= \\
=A+\int_{0}^{\tau_{k}-\tau_{0}}\left|u(\tau)-\vartheta\left(\tau+\tau_{0}\right)\right| d \tau \rightarrow \min .
\end{gathered}
$$

Taking into account (22), we write equation (23) in the form

$$
\theta_{1}(\tau, 1)=u\left(\tau-\tau_{0}\right), \quad \tau_{0}=1 / g_{0}
$$

and use the result in quality criterion (25)

$$
A=\int_{0}^{\tau_{0}}\left|\gamma\left(\tau-\tau_{0}\right)-\vartheta(\tau)\right| d \tau=\int_{-\tau_{0}}^{0}\left|\gamma(\tau)-\vartheta\left(\tau+\tau_{0}\right)\right| d \tau=\text { const. }
$$

The presence of the constant $A$ in the quality criterion indicates that the output parameters of the conveyor are uncontrollable in the time interval $\tau \in\left[0,1 / g_{0}\right]$. In the general form, the optimal control problem for the output flow of the conveyor belt can be formulated as follows [20,21]: determine the optimal control of the intensity of the material supply at the input of the conveyor belt from the accumulating bunker, that is a minimum of the integral

$$
\int_{0}^{\tau_{k}-\tau_{0}}\left|u(\tau)-\vartheta\left(\tau+\tau_{0}\right)\right| d \tau \rightarrow \min , \quad \tau_{0}=1 / g_{0}
$$

in the time interval $\tau \in\left[0, \tau_{k}\right]$ with the differential connections

$$
\frac{d n_{0}(t)}{d t}=\gamma_{\mathrm{b}}(\tau)-u(\tau)
$$

under constraints on the phase variable (21)

$$
0 \leqslant n_{0}(t) \leqslant n_{b}, \quad n_{0}(0)=n_{0 s t},
$$


under constraints on the control, and with initial conditions

$$
0 \leqslant u(\tau) \leqslant \gamma_{\max }, \quad u_{\min }<\vartheta_{\min }, \quad \vartheta_{\max }<u_{\max }, \quad 0 \leqslant u(\tau) \leqslant \gamma(\tau)=g_{0} \theta_{\max } .
$$

The Pontryagin function, Lagrange function, and the conjugate system have the form [20]:

$$
\begin{gathered}
H=-\psi_{0}\left|u(\tau)-\vartheta\left(\tau+\tau_{0}\right)\right|+\psi_{1}\left(\gamma_{\mathrm{b}}(\tau)-u(\tau)\right) \rightarrow \max , \\
L=H+\mu_{1} n_{0}+\mu_{2}\left(n_{b}-n_{0}\right), \quad \mu_{1} \geqslant 0, \quad \mu_{1} n_{0}=0, \quad \mu_{2} \geqslant 0, \mu_{2}\left(n_{b}-n_{0}\right)=0, \\
\frac{d \psi_{1}}{d t}=-\frac{\partial L}{\partial n_{0}}, \quad \psi_{1}\left(\tau_{k}-\tau_{0}\right)=0 .
\end{gathered}
$$

\section{Synthesis of the Optimal Control}

We assume that the materials enter the accumulating bunker with a constant intensity $\gamma_{\mathrm{b}}(\tau)=1,0$. The form of the function $\vartheta(\tau)$ is defined as $[22] \vartheta(\tau)=1,0+\sin (\pi \tau)$.

In the absence of phase constraints (29), taking into account (32), it should be $\psi_{1}(\tau)=$ const $=0$, and the Pontryagin function has the form

$$
H=-\left|u(\tau)-\vartheta\left(\tau+\tau_{0}\right)\right| \rightarrow \max .
$$

Therefore, we assume that the solution takes the following form:

$$
u(\tau)=\vartheta\left(\tau+\tau_{0}\right) .
$$

For the obtained control, we can write dynamics of the change in the state of the stock of materials in the accumulating bunker

$$
\frac{d n_{0}(t)}{d t}=\gamma_{\mathrm{b}}(\tau)-u(\tau)=1,0-\left(1,0+\sin \left(\pi\left(\tau+\tau_{0}\right)\right)\right)=-\sin \left(\pi\left(\tau+\tau_{0}\right)\right) .
$$

Using Laplace transform

$$
\sin \left(\pi\left(\tau+\tau_{0}\right)\right) \div \frac{\pi \cos \pi\left(\tau+\tau_{0}\right)+p \sin \pi\left(\tau+\tau_{0}\right)}{p^{2}+\pi^{2}}
$$

we obtain equation (35) in the form

$$
N_{0}(p)=\frac{n_{0 s t}}{p}-\frac{\pi \cos \left(\pi \tau_{0}\right)}{p\left(p^{2}+\pi^{2}\right)}-\frac{\sin \left(\pi \tau_{0}\right)}{p^{2}+\pi^{2}} .
$$

Hence, we can write solution (35) as

$$
n_{0}(t)=n_{0 s t}+\frac{\cos \left(\pi\left(\tau+\tau_{0}\right)\right)-\cos \left(\pi \tau_{0}\right)}{\pi} .
$$

Expression (38) determines the solution to optimal control problem (27) - (30) in the absence of phase constraints (29), Fig. 2. It is obvious that if condition (29) satisfies

$$
0 \leqslant n_{0 s t}+\frac{\cos \left(\pi\left(\tau+\tau_{0}\right)\right)-\cos \left(\pi \tau_{0}\right)}{\pi} \leqslant n_{b}
$$

then the solution with phase constraints (29) coincides with (38). Now, consider the case for which condition (39) at time $t$ is not satisfied at time $\tau$. The maximum of Pontryagin function (31) can be reached at finite values (see Table 1). This table shows the control values for which the Pontryagin function takes the maximum value. Let us consider in details the possible cases.

Pontryagin function (31) has the form

$$
u(\tau)-\vartheta\left(\tau+\tau_{0}\right) \geqslant 0, \quad H=\psi_{1} \gamma_{\mathrm{b}}(\tau)+\vartheta\left(\tau+\tau_{0}\right)-u(\tau)\left(\psi_{1}+1\right) \rightarrow \max ,
$$


Variants of controls

Table 1

\begin{tabular}{|l|l|l|l|}
\hline & $u(\tau)<\vartheta\left(\tau+\tau_{0}\right)$ & $u(\tau)=\vartheta\left(\tau+\tau_{0}\right)$ & $u(\tau)>\vartheta\left(\tau+\tau_{0}\right)$ \\
\hline$\psi_{1}<-1$ & - & - & $u_{\max }$ \\
\hline$\psi_{1}=-1$ & - & $u(\tau)=\vartheta\left(\tau+\tau_{0}\right)$ & $u(\tau)>\vartheta\left(\tau+\tau_{0}\right)$ \\
\hline$-1<\psi_{1}<0$ & - & $u(\tau)=\vartheta\left(\tau+\tau_{0}\right)$ & - \\
\hline$\psi_{1}=0$ & - & $u(\tau)=\vartheta\left(\tau+\tau_{0}\right)$ & - \\
\hline $0<\psi_{1}<1$ & - & $u(\tau)=\vartheta\left(\tau+\tau_{0}\right)$ & - \\
\hline$\psi_{1}=1$ & $u(\tau)<\vartheta\left(\tau+\tau_{0}\right)$ & $u(\tau)=\vartheta\left(\tau+\tau_{0}\right)$ & - \\
\hline$\psi_{1}>1$ & $u_{\min }$ & - & - \\
\hline
\end{tabular}
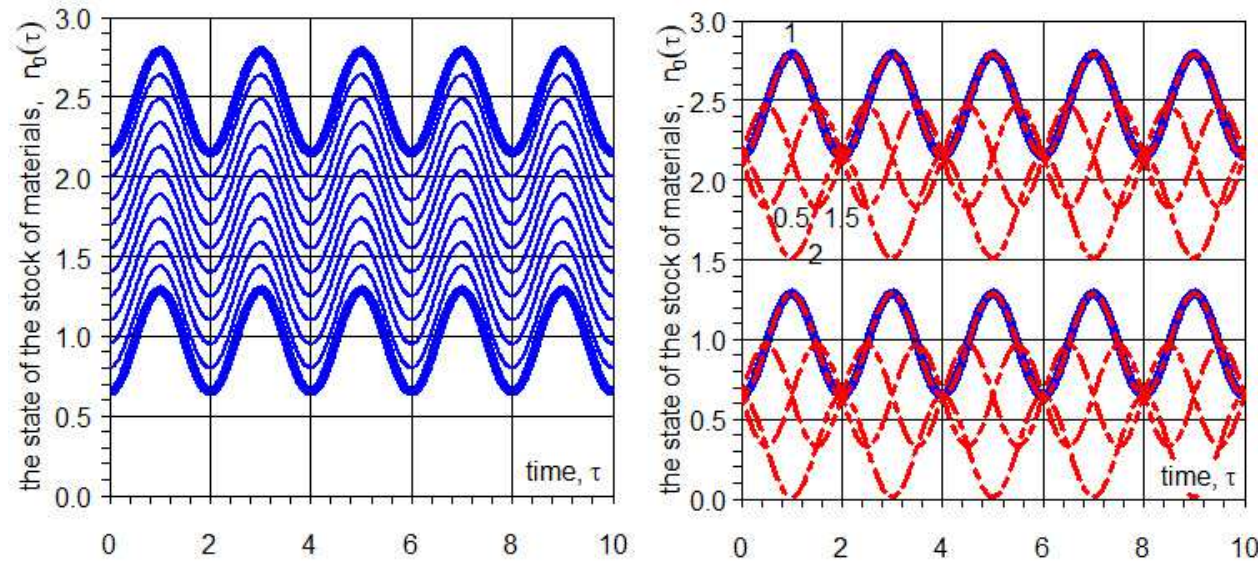

Fig. 2. Dynamics of the change in the amount of material in the bunker $n_{0}(\tau)$ (a - for initial states $n_{0 s t}=0,65+0,15 i, i=0 \ldots 10 ; \mathrm{b}-$ for $\left.\tau_{0}=\{0,5,1,0,1,5,2,0\} ; \tau_{0}=1 / g_{0}\right)$

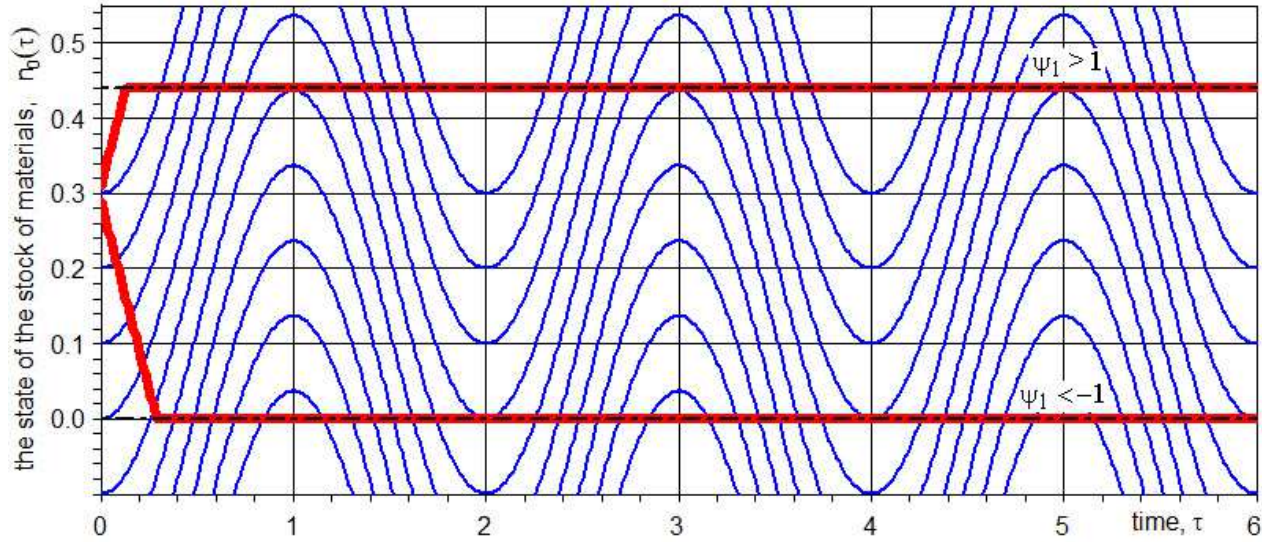

Fig. 3. Dynamics of the change in the amount of material in the bunker for the case $\psi_{1} \in[-\infty ;-1,0]$

$$
\begin{array}{ll}
u(\tau)-\vartheta\left(\tau+\tau_{0}\right)=0, & H=\psi_{1}\left(\gamma_{\mathrm{b}}(\tau)-\vartheta\left(\tau+\tau_{0}\right)\right) \rightarrow \max \\
u(\tau)-\vartheta\left(\tau+\tau_{0}\right)<0, & H=\psi_{1} \gamma_{\mathrm{b}}(\tau)-\vartheta\left(\tau+\tau_{0}\right)-u(\tau)\left(\psi_{1}-1\right) \rightarrow \max .
\end{array}
$$

1) $\psi_{1}<-1 \quad \rightarrow \quad u(\tau)=u_{\max }$. Movement begins with the size of the control $u(\tau)=u_{\max }($ Table 1$)$, and parameters $\psi_{1}(0)=\psi_{10}, n_{0}(0)=n_{0 s t}, \gamma_{\mathrm{b}}(\tau)=1,0$ :

$$
\frac{d n_{0}(t)}{d t}=1-u(\tau), \quad \frac{d \psi_{1}(t)}{d t}=-\mu_{1}+\mu_{2}
$$




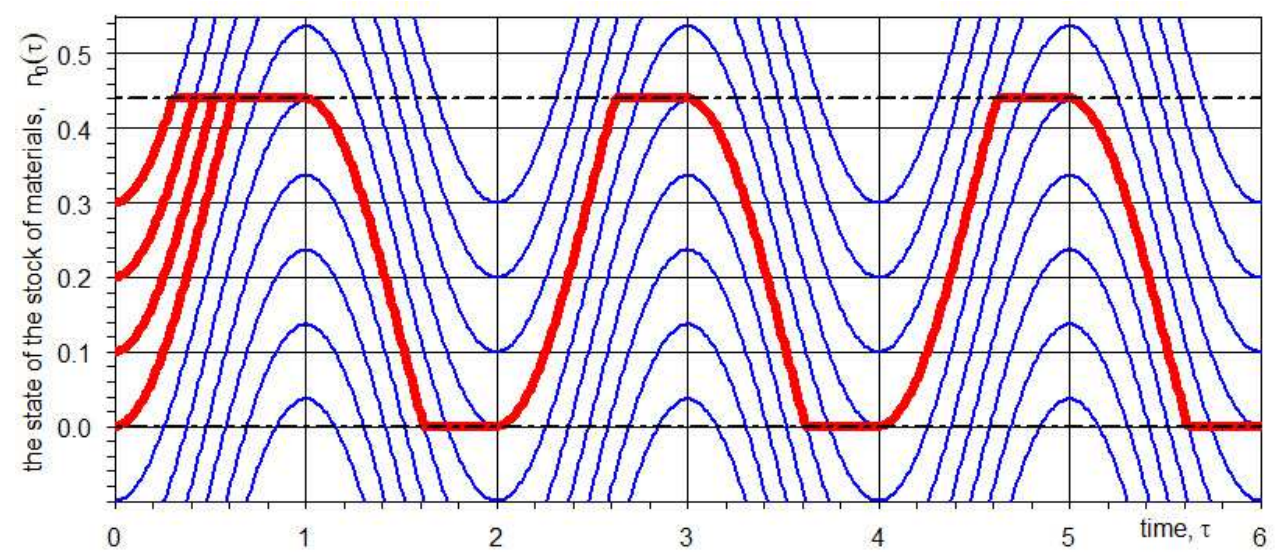

Fig. 4. Dynamics of the change in the amount of material in the bunker $n_{0}(\tau)$ when switching control $\left\{u(\tau)=\vartheta\left(\tau+\tau_{0}\right) ; u(\tau)=1,0\right\}$ at phase constraints

Solution to the system of equations is given by

$$
n_{0}(\tau)=n_{0 s t}=0, \quad \psi_{1}(t)=\psi_{10}-\mu_{1} \tau,
$$

if the value of stocks in the bunker is the lower limit, and

$$
n_{0}(\tau)=n_{0 s t}+\tau-u_{\max } \tau, \quad \psi_{1}(\tau)=\psi_{10}, \quad 0<\tau \leqslant \tau_{1}=\frac{n_{0 s t}}{u_{\max }-1}
$$

otherwise. For $\tau \geqslant \tau_{1}$, the value of the phase variable $n_{0}(\tau)$ reaches the lower limit $n_{0}\left(\tau_{1}\right)=$ 0 and remains

$$
n_{0}(\tau)=n_{0 s t}=0, \quad \psi_{1}(\tau)=\psi_{10}-\mu_{1}\left(\tau-\tau_{1}\right) .
$$

Condition $\psi_{1}\left(\tau_{k}-\tau_{0}\right)=0$ (32) is not met (Fig. 3). It contradicts the assumption of the existence of a solution and the maximum principle $[20,21]$.

2) $\psi_{1}>1 \rightarrow u(\tau)=u_{\min }$. Similarly to the previous case, condition $\psi_{1}\left(\tau_{k}-\tau_{0}\right)=0$ (32) is not met (Fig. 3).

3) $-1<\psi_{1}<0$ and $0<\psi_{1}<1$. It contains a valid solution for $u(\tau)=\vartheta\left(\tau+\tau_{0}\right)$. In fact, for $u(\tau)>\vartheta\left(\tau+\tau_{0}\right)$ we have $u(\tau)=u_{\min }$, but $u(\tau)=u_{\min }<\vartheta\left(\tau+\tau_{0}\right)$. We obtain a contradiction with the initial condition. The case $\psi_{1}=1$ also leads to optimal control $u(\tau)=\vartheta\left(\tau+\tau_{0}\right)$.

4) $\psi_{1}=-1$. The initial control $u(0)$ must be such that the lower limit is not reached first. Otherwise, the phase coordinate $n_{0}(\tau)$ remains at the lower limit. This gives the following condition on the control: $u<\gamma_{\mathrm{b}}(\tau)=1$.

5) $\psi_{1}=1$. In this case, for the same reasons, the initial control $u(0)$ must be such that the upper limit is not reached first. Otherwise, the phase coordinate $n_{0}(\tau)$ remains at the upper limit. This gives the following condition on the control: $u>\gamma_{\mathrm{b}}(\tau)=1$. A family of phase trajectories is shown in (Fig. $4-6$ ). The family of phase trajectories meets criterion of the control quality (27). Fig. 4 demonstrates the control algorithm. The control $u(\tau)=\vartheta\left(\tau+\tau_{0}\right)$ is used at the start of the conveyor belt. Then, $u(\tau)=1,0$. It makes possible to ensure a constant amount of materials in the bunker $n_{0}(\tau)=n_{b}$. The bunker is completely filled. The excess amount of materials is fed to the input of the conveyor belt. The supply of materials exceeds requirements, $u(\tau)>\vartheta\left(\tau+\tau_{0}\right)$. A further increase in the demand for the input flow results in the phase variable $n_{0}(\tau)$ coming off the phase constraint $n_{0}(\tau)=n_{b}$. The amount of material in the bunker is reduced. The control 


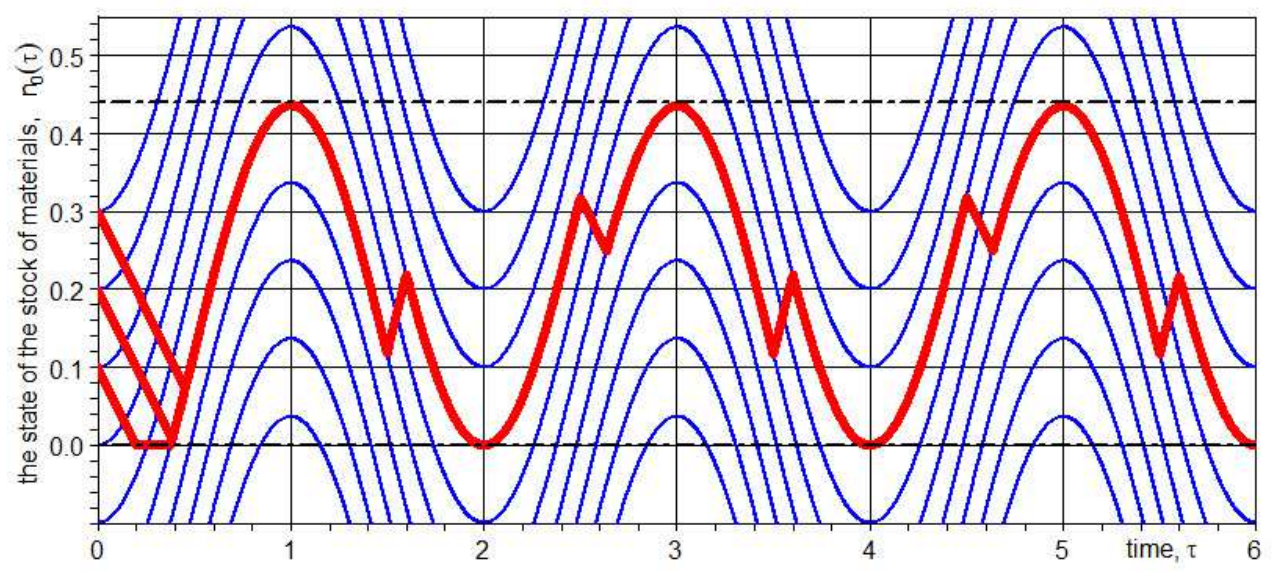

Fig. 5. Dynamics of the change in the amount of material in the bunker $n_{0}(\tau)$ for the controls $\left\{u(\tau)=1,5 ; u(\tau)=\vartheta\left(\tau+\tau_{0}\right) ; u(\tau)=0 ; u(\tau)=\vartheta\left(\tau+\tau_{0}\right)\right\}$

$u(\tau)=\vartheta\left(\tau+\tau_{0}\right)$ is supported until the lower limit $n_{0}(\tau)=0$ is reached. Then, the control $u(\tau)=1,0)$ is used. All material entering the bunker is fed to the input of the conveyor belt, $u(\tau)<\vartheta\left(\tau+\tau_{0}\right)$. Such control is maintained until the demand for the material reaches the exit point from the constraint. The cycle is repeated. Finally, the control algorithm can be formulated as follows. For constraints $u(\tau)=1,0$ and $u(\tau)=\vartheta\left(\tau+\tau_{0}\right)$ beyond the constraints. Note that the phase constraints change the conjugate variable $\psi_{1}(t), \frac{d \psi_{1}(t)}{d t} \neq 0$. Fig. 4 demonstrates the control algorithm when the switching points of the control are such that allow to avoid reaching the upper and lower limits for the phase variable $n_{0}(\tau)$. The initial movement is carried out from points $n_{0}(\tau)=\{0,1 ; 0,2 ; 0,3\}$ with the constant initial intensity $u(\tau)=1,5$ of the input of materials to the conveyor input. It provides an output for $n_{0}(\tau)$ onto the phase trajectory, which touches the constraint at the top point. The control $u(\tau)=\vartheta\left(\tau+\tau_{0}\right)$ is maintained until it is advisable to make a transition to the phase trajectory, which touches the constraint at its lowest point. The transition to the phase trajectory is performed with control $u(\tau)=0$. The new phase path $u(\tau)=\vartheta\left(\tau+\tau_{0}\right)$ is controlled by the next switching point. The control algorithm can be formulated as follows. We use $u(\tau)=1,5$ to go to the phase trajectory, which touches the upper limit, and $u(\tau)=0,0)$ for the transition to the phase trajectory, which touches the lower limit. Control between transitions is supported by $u(\tau)=\vartheta\left(\tau+\tau_{0}\right)$. We draw attention to the fact that for $\psi_{1}(0)=0$ the phase trajectory is also sustained $\psi_{1}(t)=0$. The control algorithm that determines the behavior of the phase variable $n_{0}(\tau)$ in Fig. 6 is similar to the algorithm that determines the behavior of the phase variable $n_{0}(\tau)$ in Fig. 5 . The difference is that all transitions are performed under optimal control $u(\tau)=1$ ). The control algorithm $\left\{u(\tau)=\vartheta\left(\tau+\tau_{0}\right) ; u(\tau=1,0)\right\}$ is similar to the algorithm in Fig. 4 . With the same control chosen for phase trajectories $u(\tau)=\vartheta\left(\tau+\tau_{0}\right)$ and transitions $u(\tau=1)$, the control switching points are arranged such that to avoid reaching the upper and lower limits. Let us define the costs that characterize the transition from a phase trajectory that touches the upper limit to a phase trajectory that touches the lower limit. Let us define the equation of the trajectory we want to go:

$$
n_{01}(\tau)=n_{01}\left(\tau_{1}\right)+\int_{\tau_{1}}^{\tau}\left(\gamma_{\mathrm{b}}(\tau)-\vartheta\left(\xi+\tau_{0}\right)\right) d \xi .
$$




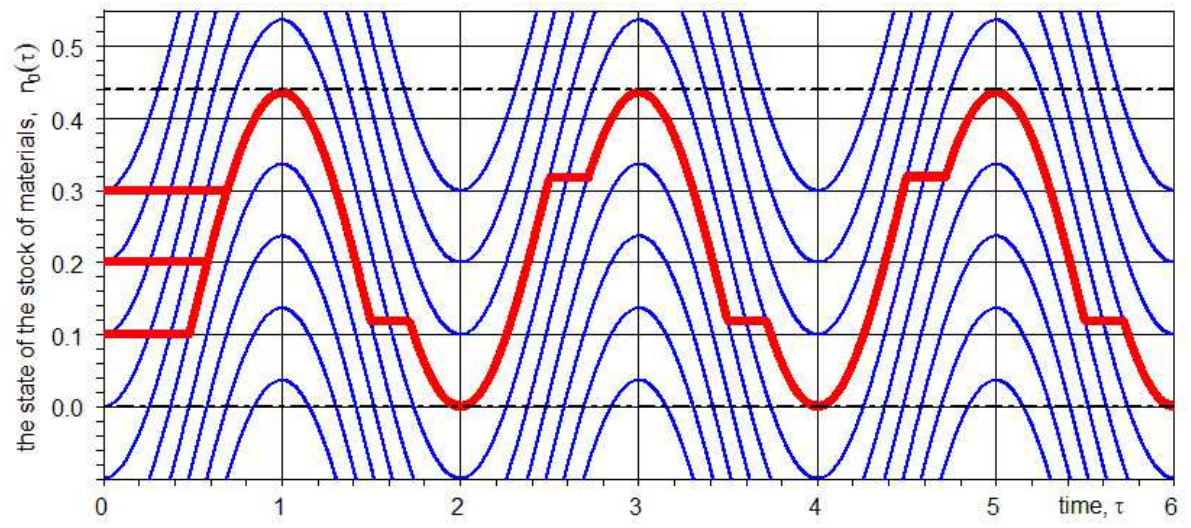

Fig. 6. Dynamics of the change in the amount of material in the bunker $n_{0}(\tau)$ at the controls $\left\{u(\tau)=\vartheta\left(\tau+\tau_{0}\right) ; u(\tau)=1,0\right\}$

The transition is carried out along the trajectory

$$
n_{02}(\tau)=n_{02}\left(\tau_{1}\right)+\int_{\tau_{1}}^{\tau}\left(\gamma_{\mathrm{b}}(\tau)-u(\xi)\right) d \xi,
$$

which is determined by the control $u(\tau)$. At any instant in time, these trajectories are valid $n_{02}\left(\tau_{1}\right)-n_{01}\left(\tau_{1}\right)=\Delta n_{0}\left(\tau_{1}\right)=$ const. This allows us to write

$$
\begin{gathered}
n_{02}(\tau)-n_{01}(\tau)=n_{02}\left(\tau_{1}\right)+\int_{\tau_{1}}^{\tau}\left(\gamma_{\mathrm{b}}(\tau)-u(\xi)\right) d \xi-n_{01}\left(\tau_{1}\right)-\int_{\tau_{1}}^{\tau}\left(\gamma_{\mathrm{b}}(\tau)-\vartheta\left(\xi+\tau_{0}\right)\right) d \xi=0, \\
\left|\Delta n_{0}\left(\tau_{1}\right)\right|=\int_{\tau_{1}}^{\tau}\left|u(\xi)-\vartheta\left(\xi+\tau_{0}\right)\right| d \xi=\text { const, }
\end{gathered}
$$

since the transition is carried out both in the forward and reverse direction. The last expression is a consequence of the given quality criterion (27). The arbitrariness of the choice of the moment of time determines the arbitrariness of the choice of control switching points, which determines the set of solutions to the problem.

\section{Conclusions and Recommendations}

The article analyzes the PDE-model of the conveyor transport system and synthesizes a family of optimal control of the flow of materials coming from the accumulating bunker to the input of the conveyor transport system. The criterion of the quality of the control of the output flow from the conveyor belt is determined, and the optimal control problem for the transport system is formulated. The analysis of admissible solutions to the control problem is carried out. The results presented in the paper allows to make the following conclusions:

- a system to control the output flow on the conveyor belt from an accumulating bunker at the input can have a large number of algorithms;

- the switching points of the optimal control are determined from a large set of feasible solutions;

- the set of admissible optimal controls is determined by the size of the accumulating bunker. 
Prospect for further research is the synthesis of optimal control for the conveyor system with input and output accumulating bunker.

\section{References}

1. Shahmejster L.G., Dmitriev V.G., Lobachjova A.K. Dinamika gruzopotokov i regulirovanie skorosti lentochnyh konvejerov [Dynamics of Traffic and Speed Control Belt Conveyors]. Moscow, Nedra, 1972. (in Russian)

2. Lauhoff H. Speed Control on Belt Conveyors - Does it Really Save Energy? Bulk Solids Handling, 2005, vol. 25, no. 6, pp. 368-377.

3. Halepoto I.A., Shaikh M.Z., Chowdhry B.S. Design and Implementation of Intelligent Energy Efficient Conveyor System Model Based on Variable Speed Drive Control and Physical Modeling International. Journal of Control and Automation, 2016, vol. 9, no. 6, pp. 379-388. DOI: $10.14257 /$ ijca.2016.9.6.36

4. BARTEC GmbH. Available at: www.bartec-group.com (accessed 2018).

5. Pihnastyi O.M., Khodusov V.D. Model of Conveyer with the Regulable Speed. Bulletin of the South Ural State University. Series: Mathematical Modelling, Programming and Computer Software, 2017, vol. 10, no. 4, pp. 64-77. DOI: 10.14529/mmp170407

6. Razumnyi Ju.T., Ruhlov A.V., Kozar A.V. Improving the Energy Efficiency of Coal Mine Conveyor Transport. Gornaja jelektromehanika $i$ avtomatika, 2006, no. 76, pp. 24-28. (in Russian)

7. Procenko S.N. Reduced Energy Consumption in Coal Mine Conveyor Transport. Gornaja jelektromehanika $i$ avtomatika, 2008, no. 81, pp. 31-40. (in Russian)

8. Prokuda V.N., Mishanskij Ju.A., Procenko S.N. Research and Evaluation of Cargo Traffic on the Main Conveyor Transport PSP "Mine Pavlogradskaya" PAO DTEK "Pavlogradugol". Gornaja jelektromehanika, 2012, no. 88, pp. 107-111. (in Russian)

9. Hiltermann J., Lodewijks G., Schott D.L. A Methodology to Predict Power Savings of Troughed Belt Conveyors by Speed Control. Particulate Science and Technology, 2011, vol. 29, no. 1, pp. 14-27. DOI: 10.1080/02726351.2010.491105

10. Continous conveyors. Belt conveyors for loose bulk materials. Basics for calculation and dimensioning. DIN 22101:2002-08. Available at: https://din.de (accessed 2002).

11. Semenchenko A., Stadnik M., Belitsky P., Semenchenko D., Stepanenko O. The Impact of an Uneven Loading of a Belt Conveyor on the Loading of Drive Motors and Energy Consumption in Transportation. Eastern-European Journal of Enterprise Technologies, 2016, vol. 82, no. 4, pp. 42-51. DOI: $10.15587 / 1729-4061.2016 .75936$

12. Conveyor Belt. Available at: http://conveyorbeltguide.com (accessed 2018).

13. Shahmejster L.G., Dmitriev V.G. Teorija $i$ raschet lentochnyh konvejerov [Theory and Calculation of Belt Conveyors]. Moscow, Mashinostroenie, 1978. (in Russian)

14. Shahmejster L.G. Veroyatnostnye metody rascheta transportiruyushchih mashin [Probabilistic Methods for Calculating Transport Vehicles], Moscow, Mashinostroenie, 1983. (in Russian)

15. Demuckii V.P., Pihnastaja V.S., Pihnastyi O.M. [Stability of Functioning Mass Production and Product Promotion on The Market]. Kharkov, HNU, 2003.

16. Armbruster D., Marthaler D., Ringhofer C., Kempf K., Tae Chang Jo. A Continuum Model for a Re-Entrant Factory. Operations research, 2006, vol. 54, no. 5, pp. 933-950. DOI: $10.1287 /$ opre.1060.0321 
17. Pihnastyi O.M. Statisticheskaya teoriya proizvol'nyh sistem [Statistical Theory of Production Systems]. Kharkov, HNU, 2007.

18. Pihnastyi O.M., Hodusov V.D. [Diffusion Description of the Production Process]. Matematicheskoe modelirovanie. Informacionnye tehnologii. Avtomatizirovannye sistemy upravlenija, 2017, vol. 35, pp. 61-73. (in Russian)

19. Pihnastyi O.M., Hodusov V.D. [Model of a Single-Node Conveyor Line with a Constant Speed of Movement of Objects of Labor]. Matematicheskoe modelirovanie. Informacionnye tehnologii. Avtomatizirovannye sistemy upravlenija, 2016, vol. 32, pp. 60-74. (in Russian)

20. Pontrjagin L.S., Boltjanskij V.G., Gamkrelidze R.V. Matematicheskaya teoriya optimal'nyh processov [Mathematical Theory of Optimal Processes]. Moscow, Nauka, 1983. (in Russian)

21. Moiseev N.N. Jelementy teorii optimal'nyh sistem [Elements of the Theory of Optimal Systems]. Moscow, Nauka, 1974. (in Russian)

22. La Marca M., Armbruster D., Herty M., Ringhofer C. Control of Continuum Models of Production Systems. IEEE Transactions on Automatic Control, 2010, vol. 55, no. 11, pp. 2511-2526. DOI: 10.1109/TAC.2010.2046925

Received April 20, 2018

УДК 658.51.012

DOI: $10.14529 / \mathrm{mmp} 190206$

\section{ЗАДАЧА ОПТИМАЛЬНОГО УПРАВЛЕНИЯ ВЫХОДНЫМ МАТЕРИАЛЬНЫМ ПОТОКОМ КОНВЕЙЕРНОЙ ЛИНИИ С ВХОДНЫМ НАКОПИТЕЛЬНЫМ БУНКЕРОМ}

\section{О.М. Пигнастыйї, В.Д. Ходусов}

${ }^{1}$ Национальный технический университет «ХПИ», г. Харьков, Украина

${ }^{2}$ Харьковский национальный университет им. В.Н. Каразина, г. Харьков, Украина

Статья посвящена синтезу оптимальных управлений производственных поточных линий с входным аккумулирующим бункером. Основное внимание уделяется модели конвейерной линии с постоянной скоростью движения ленты. Моделирование конвейерной линии выполнено в одномоментном приближении с использованием уравнений в частных производных. Конвейерная линия представлена как распределенная система. Использованная PDE-модель конвейерной линии позволила определить состояние потоковых параметров для заданной технологической позиции в виде функции времени. Рассмотрена задача оптимального управления потоковыми параметрами конвейерной линии, которая заключается в обеспечении минимального отклонения выходного грузопотока от заданного планового значения. Управление осуществляется величиной грузопотока материала, поступающего из аккумулирующего бункера на вход конвейерной линии. При синтезе оптимальных управлений учтены ограничения на размер аккумулирующего бункера и ограничения на величину управления. Построено оптимальное управление величиной грузопотока, поступающего из аккумулирующего бункера, и определены условия переключения режимов управления. Выполнена оценка периода времени между моментами переключения режимов управления.

Ключевые слова: конвейер; производственная линия; предмет труда; поточная линия; РDE-модель производства; параметры состояния поточной линии; технологическая позиция; переходной период; системы управления производством; оптимальное управление; функиия Понтрягина; функция Лагранжа; дифференциальные связи; аккумулирующий бункер; распределенная система.

Вестник ЮУрГУ. Серия «Математическое моделирование

и программирование» (Вестник ЮУрГУ ММП). 2019. Т. 12, № 2. С. 67-81 


\section{Литература}

1. Шахмейстер, Л.Г. Динамика грузопотоков и регулирование скорости ленточных конвейеров / Л.Г. Шахмейстер, В.Г. Дмитриев, А.К. Лобачева. - М.: Недра, 1972.

2. Lauhoff, H. Speed Control on Belt Conveyors - Does it Really Save Energy? / H. Lauhoff // Bulk Solids Handling. - 2005. - V. 25, № 6. - P. 368-377.

3. Halepoto, I.A. Design and Implementation of Intelligent Energy Efficient Conveyor System Model Based on Variable Speed Drive Control and Physical Modeling / I.A. Halepoto, M.Z. Shaikh, B.S. Chowdhry // International Journal of Control and Automation. - 2016. V. 9. - № 6. - P. 379-388. DOI: 10.14257/ijca.2016.9.6.36

4. BARTEC GmbH (Germany). - 2017. URL: www.bartec-group.com.

5. Pihnastyi, O.M. Model of Conveyer with the Regulable Speed / O.M. Pihnastyi, V.D. Khodusov // Вестник ЮУрГУ. Серия: Математическое моделирование и программирование. - 2017. - Т. 10, № 4. - С. 64-77.

6. Разумный, Ю.Т. Повышение энергоэффективности конвейерного транспорта угольных шахт / Ю.Т. Разумный, А.В. Рухлов, А.В. Козарь // Горная электромеханика и автоматика. - 2006. - № 76. - С. 24-28.

7. Проценко, С.Н. Снижение энергопотребления на конвейерном транспорте угольных шахт / С.Н. Проценко // Горная электромеханика и автоматика. - 2008. - № 81. C. $31-40$.

8. Прокуда, В.Н. Исследование и оценка грузопотоков на магистральном конвейерном транспорте ПСП «Шахта Павлоградская» ПАО ДТЭК «Павлоградуголь» / В.Н. Прокуда, Ю.А. Мишанский, С.Н. Проценко // Горная электромеханика. - 2012. - № 88. C. $107-111$.

9. Hiltermann, J. A Methodology to Predict Power Savings of Troughed Belt Conveyors by Speed Control / J. Hiltermann, G. Lodewijks, D.L. Schott, J.C. Rijsenbrij, J. Dekkers, Y. Pang // Particulate Science and Technology. - 2011. - № 29. - P. 14-27.

10. Continous Conveyors. Belt Conveyors for Loose Bulk Materials. Basics for Calculation and Dimensioning. DIN 22101:2002-08. - URL: www.din.de.

11. Semenchenko, A. The Impact of an Uneven Loading of a Belt Conveyor on the Loading of Drive Motors and Energy Consumption in Transportation / A. Semenchenko, M. Stadnik, P. Belitsky, D. Semenchenko, O. Stepanenko // Eastern-European Journal of Enterprise Technologies. - 2016. - № 4. - P. 42-51.

12. Conveyor Belt. - 2018. URL: http://conveyorbeltguide.com.

13. Шахмейстер, Л.Г. Теория и расчет ленточных конвейеров / Л.Г. Шахмейстер, В.Г. Дмитриев. - М.: Машиностроение, 1978.

14. Шахмейстер, Л.Г. Вероятностные методы расчета транспортирующих машин / Л.Г. Шахмейстер. - М.: Машиностроение, 1983.

15. Демуцкий, В.П. Теория предприятия: Устойчивость функционирования массового производства и продвижения продукции на рынок / В.П. Демуцкий, В.С. Пигнастая, О.М. Пигнастый. - Харьков: ХНУ, 2003.

16. Armbruster, D.A Continuum Model for a Re-Entrant Factory / D. Armbruster, D. Marthaler, C. Ringhofer, K. Kempf, Tae Chang Jo // Operations Research. - 2006. - V. 54 - № 5. P. 933-950.

17. Пигнастый, О.М. Статистическая теория производственных систем / О.М. Пигнастый. Харьков: ХНУ, 2007. 
18. Пигнастый, О.М. Диффузионное описание производственного процесса / О.М. Пигнастый, В.Д. Ходусов // Математическое моделирование. Информационные технологии. Автоматизированные системы управления. - 2017. - № 35. - С. 61-73.

19. Пигнастый, О.М. Модель одноузловой конвейерной линии с постоянной скоростью перемещения предметов труда / О.М. Пигнастый, В.Д. Ходусов // Математическое моделирование. Информационные технологии. Автоматизированные системы управления. 2016. - № 32. - C. 60-74.

20. Понтрягин, Л.С. Математическая теория оптимальных процессов / Л.С. Понтрягин, В.Г. Болтянский, Р.В. Гамкрелидзе. - М.: Наука, 1983.

21. Моисеев, Н.Н. Элементы теории оптимальных систем / Н.Н. Моисеев. - М.: Наука, 1974.

22. La Marca, M. Control of Continuum Models of Production Systems / M. La Marca, D. Armbruster, M. Herty, C. Ringhofer // IEEE Transactions on Automatic Control. 2010. - V. 55, № 11. - P. 2511-2526.

Олег Михайлович Пигнастый, доктор технических наук, профессор, кафедра «Компьютерный мониторинг и логистика», Национальный технический университет «ХПИ» (г. Харьков, Украина), pom7@bk.ru.

Валерий Дмитриевич Ходусов, доктор физико-математических наук, профессор, кафедра «Теоретическая ядерная физика и высшая математикв им. А.И. Ахиезера», Харьковский национальный университет им. В.Н. Каразина (г. Харьков, Украина), vkhodusov@ukr.net.

Поступила в редакиию 20 апреля 2018 г. 